\title{
Global warming affects on Fishing village in India (A case study on Andhra coastal village: Uppada)
}

\author{
Ch. Guru prasad ${ }^{1}$, Gaddem. Narasimha Rao ${ }^{2}$ \\ ${ }^{I}$ ( Research scholar Department of Environmental sciences , ANU, Guntir,(A.P), INDIA) \\ ${ }^{2}$ (Geologist in Pokarna Granite Ltd and Post PG Student in ANU,Guntur,(AP),INDIA)
}

\begin{abstract}
People living near cliffs and shorelines at risk. The great concentration of National resources in coastal zones makes it imperative that coastal change is well understood. Sea level has risen about $40 \mathrm{~cm}$ in the past century and is projected to rise another $60 \mathrm{~cm}$ in the next century. Due to global warming, average rise of sea level is of the order of 1.5 to $10 \mathrm{~mm}$ per year. It has been observed that sea level rise of $1 \mathrm{~mm}$ per year could cause a recession of shoreline in the order of about $0.5 \mathrm{~m}$ per year. Andhra Pradesh has a coastline of $974 \mathrm{~km}$. Among which the Bay of Bengal Sea. Coast has frequently been affected by cyclones and inundated by storm surges. Erosion is noticed at Uppada, Visakhapatnam and Bhimunipatnam.in Andhra Pradesh coastal areas. Recent research is making it increasingly clear that climate change will change and damage the coastal environment. Now presented in this paper causes, effects and remedial techniques, it is useful to the disaster and risk management studies, planer, geo- morphologists, environmental researchers, academicians and administrators.
\end{abstract}

Key words: Bay of Bengal, Cyclone, Erosion, Sea level, Technique

\section{Introduction}

The coastal environment is a unique because mangroves forest, coral reefs, sea beaches, sea weeds, tidal flats and daily tide, waves etc. are found only at the coast. The terrestrial and marine process such as wind actions, tide, wave, currents, erosion /accretion etc continuously influence the coastal zone and make it dynamic and fragile. It contains a wide range of natural resources, productive and valuable habitat of the biosphere such as mangroves, coral reefs, saltpans, salt-marsh, creeks, estuary, beach, sand dune estuary, lagoons, coastal wetlands and mud-flat etc. It also provides important services such protecting shoreline and absorbing flood water as filtering of pollution, retaining nutrients, maintaining water quality. Due to its unique location benefited environment, fertile lowland, abundant marine resources, water transportation, aesthetic beauty etc., people are attracted to live, to commerce, to military and to a variety of industries from ancient time to the present. It is an area of high economic significance due to faster economic development. Two-thirds of the worlds cities occur on the coast . But the coastal zones are facing a lot of problems. They are landfill, dredging, and pollution caused by urban, industrial and agricultural development, coastal erosion, loss of coastal habitat, storm surge, tsunami and the global warming induced sea level rise etc. Coastal erosion is caused due to both natural processes and anthropogenic interventions. The unceasing act of winds, waves, tides and currents leads to shore movement or littoral drift along certain coastal stretches. The imbalance created or the lack of littoral material supply thus makes the land lose by erosion, which, at places will be permanent. The concentration of wave energy due to wave refraction further accelerates erosion. These effects will also impact severely upon human society.

A large and growing part of the population now lives close to coasts. The threats posed to coastal populations and infrastructure by rising sea levels and extreme events such as storm surges. There is an urgent need for action now in order to limit the adverse effects of climate change upon ecosystems and human society. Coastal erosion happens primarily as a result of sea level rise, intense storm action, and changed or more intensive wave action. In the upland areas, the increased intensity of rains leads to the Erosion of forest land. In the coastal areas, there is less evidence for sea level rise, but intense Storms and increased wave action have certainly accelerated the rate of erosion in several coastal areas. This is especially significant in districts where major rivers open into the Bay of Bengal - e.g., East \& West Godavari, Krishna and Guntur. The natural processes of erosion are aggravated by the human-induced changes to the Environment. Several coastal villages experience an increase in the intensity of erosion which leads to loss of long stretches of coastline and damage to properties annually. Erosion of the shoreline has reduced space for living and for fisheries, Stalinized freshwater sources, and increased population pressure in the hinterland. In this study Uppada village in East Godavari district providing the most severe of the impacts of erosion Andhra Pradesh. 


\subsection{Coastal Zone Management Issues}

A combined approach to coastal protection and resource conservation simplifies the process of management and leads to more balanced decisions on what constitutes acceptable development. The setback requirement that protects beachfront structures from erosion and storm waves can also preserve turtle-nesting sites on the back beach. Similarly, restriction on clearing of mangrove swamps will not only conserve an economically valuable resource, but also maintain a physical defense against storm tides. Severe beach erosion is a problem of all coastal nations. A long coastline of about $7,516 \mathrm{~km}$ of flat coastal terrain, shallow continental shelf, high population density, geographical location and physiological features of its coastal areas makes India, in the North Indian Ocean (NIO) Basin, extremely vulnerable to cyclones and its associated hazards like storm tide (the combined effects of storm surge and astronomical tide), high velocity wind and heavy rains.

Though the frequency of Tropical Cyclones (TCs)in the NIO covering the Bay of Bengal and theArabian Sea is the least in the world (7\% of the global total), their impact on the east coast of India as well as the Bangladesh coast is relatively more devastating. This is evident from the fact that in

the last 270 years, 21 of the 23 major cyclones (with a loss of about 10,000 lives or more) worldwide occurred over the area surrounding the Indian subcontinent (India and Bangladesh). This is primarily due to the serious storm tide effect in the Thirteen coastal states and Union Territories (UTs) in the country, encompassing 84 coastal districts, are affected by tropical cyclones. Four states (Tamil Nadu, Andhra Pradesh, Orissa and West Bengal) and one UT (Pondicherry) on the east coast and one state (Gujarat) on the west coast are more Vulnerable to hazards associated with cyclones.

1. Causes for sea erosion in the selective area.

2. Effects on living hoods

3. Measure and techniques

\section{Description of The Study}

Andhra Pradesh coast are quite intensive and have been highly productive both from food production and economy points of view while on the other the coast has been subjected to a number of natural hazards which are quite frequent, sudden and unwarranted. The summer monsoon depressions and severe storms cause extensive loss of life, apart from severe damage to property and crops across the Andhra coast. In addition to these unwarranted events, a regular and cyclic phenomena like erosion and deposition is prevalent in many parts of the A.P. coast. One of the striking examples is severe erosion that has been significantly damaging the Kakinada-Uppada coast. Andhra Pradesh state has $900 \mathrm{~km}$ of coastline on the east coast of India and an estimated 870,000 fishers living mainly in fishing communities. Uppada is a sea fishing community of around 13,000 inhabitants. The community has changed considerably over time: technological advances have influenced the types of boats used and the variety of fishing gear, and coastal erosion has seen the village move several times. The increasing globalisation of the fishing industry - particularly the advent of shrimp fishing, has impacted upon Uppada (e.g. affecting catch prices). Alternative communal resources are limited in Uppada.

\section{Methodology}

Present and past topographical changes, and characteristics wave and climate data, The present day the sea level rise a great topic of discussion because of its acceleration and have potential of huge impacts on the low lying coastal zone, because of the coastal zone is highly resourceful, dynamic and highly densely populated. So, it needs the proper management of coastal areas, keeping in mind the climate change and global warming induced accelerating sea level rise. The coastal vulnerability index highlights those coastal segments where the effects of sea-level rise might be the greatest, i.e. where there is the greatest chance that physical changes will occur as sea-level rises. Hence, the coastal vulnerability.

\subsection{Population pressure}

\section{Challenges Facing at Uppada Village}

Fishing in East Godavari District is shaped largely by its physical geography which sub-divides the district into two ecological zones. This is evident from the development of different modes of fishing and the distribution of castes specializing in these different modes. South of Kakinada is the Godavari River Delta. The northern part of the delta is mangroves which drain into Kakinada Bay, enclosed by the sand spit of Hope Island. This ecological zone is dominated by the Agnikula Kshatriya caste who are traditionally river fishers. Increasingly, members of the Agnikula Kshatriya use small wooden crafts and rafts to fish in Kakinada Bay. All the mechanised boats using trawling gear owned by fisher castes are Agnikula Kshatriya who have migrated predominately to Yetimoga on the outskirts of Kakinada. A major factor underpinning the tragedy of the commons, as well as several other manifestations of stress on the livelihoods of the communities, has been the 
enormous growth in population size in the coastal districts over the last three decades. Most communities have doubled their populations over this period, which resulted in further demands on the natural resources as well as more pressure on the living conditions.

\subsection{Wave/tidal actions}

Changes in tidal and wave actions have been mostly reported by the people involved in fishing and related activities, although their deeper effects - increased salinisation of ground water, erosion and reduced living space - are felt more widely. As a result of increased intensity of wave actions, the shoreline does not slope gently into the sea allowing the tides and waves to play out their energies before reaching the beach; it drops abruptly into the sea, causing the waves to be more intense and damaging when they hit the shoreline.

\subsection{Natural disasters}

Although an increase in natural disasters like cyclones is considered to be a strong indicator of climate change, there is less evidence that this is happening in the coastal districts of Andhra Pradesh. The incidence of cyclones may have remained largely the same as ever, what may have increased is their intensity and their area of distribution. The last two cyclones to have hit the Andhra Pradesh coast - Cyclone Laila and Cyclone Nilam in 2013 november philin and hellen cyclones have left significant damages in their wake, affecting agriculture and fisheries very badly. Another critical change with respect to the cyclones has been that they too have ceased to be seasonal: specific months - May \& November - were considered as the 'cyclone months' and the administration could be prepared to deal with them in those months. Unlike in the Again, as with everything that we have discussed so far (reduced freshwater downstream vs reduced seawater upstream; increased erosion in one place vs increased siltation at another), there is also a flipside to the incidence of floods. According to the coastal fishers, annual monsoonal floods, which allowed a good mix of fresh and saline waters, reduced seawater temperatures and brought nutrients into the sea, were a necessary requisite for the wellbeing of their fisheries. However, with the loss of regularity of the floods, this is not happening and that - according to the fishers - is one reason for the poor fish catches in their areas. A few trends relating to climate change, e.g., change in wind patterns and rainfall, seasonal fluctuations and natural disasters, are attributed to the natural factors. For the respondents, the global phenomena such as sea-level rise, global warming and El Nino Effect, are totally new ideas and their ability to relate a change in their local environment actions.

\subsection{Damage Overview}

Data for this damage assessment has been collected through field visits to each of the main affected stretches of coastline; review of state government damage assessment reports and technical reports; and consultation with relevant divisions in each district. Although the overall impact of the tsunami on the east coast was severe, damage to coastal protection structures was limited. Most are designed to cope with high wind waves, and survived the tsunami with only minor damage. The Rubble Mound Seawalls (RMSs) survived and were reported to have saved many lives and properties. However, most of the small coastal embankments to protect roads and other infrastructure did not have sufficient depth to cope, and suffered severe damage.

\subsection{Toxicants to fish culture}

Some fishers in all sectors believe that pollution, especially from industry, agriculture, and shrimp hatcheries is causing a decline in fishing stocks. Intensive agriculture in the delta and the opening of new irrigation schemes near Uppada are having an impact on estuary fishing, as well as marine fishing. Shrimp are dying in aquaculture ponds in part due to pollution from the water supply. The major factor is infections from white spot virus. However, aqua culturalists claim that the lack of resistance of shrimp to the virus is caused by polluted water. Aqua culture in turn is adding its own waste to the pollution problem. Aqua culture was started in the district in the 1980's. According to one senior fisheries scientist, aqua culture itself is a major polluter. Those managing aquaculture ponds in the research area reported serious problems with water pollution. According to them, the water used to fill the ponds is polluted and is a major factor in the high incidence of white spot virus. Those managing ponds unaffected by the virus claim that the high incidence in other ponds is due to unhygienic practice. The effluent from all ponds is dumped into nearby estuaries. 57 Shrimp hatcheries are also blamed as contributing to pollution by all fishers. However, the shrimp hatchery owners claim that their water is filtered before recycling into the sea and that their waste is negligible. Some Fisheries Officers agree that the hatcheries are not causing pollution. However, some Fisheries Officers, and even the owners, acknowledge that the high levels of anti-biotic may be influencing fish development and reproduction. On the other hand, one Pollution Control Board official claimed that their data on effluents from hatcheries and aquaculture show that they are not polluting. With regard to hydro-petrol depots, the Pollution Control Board in Kakinada does not expect pollution from this source. The PCB is regularly renewing and reviewing these depots. There are dykes around the plants to prevent leakage and spillage from entering surrounding land. The 
industry is very careful because hydropetrol is highly explosive. One senior fisheries scientist official thought that pollution is much better today than 15 years ago. However, pollution remains a major problem which he attributed to the fact that even with clearance of PCB, industries do not always comply. All pollutants go to the sea, directly or through natural drainage system of creeks and rivers. More seriously he pointed out that there is no research on the impact of pollution on the sea and the fish and other organisms living in it.

\subsection{Beach Erosion}

Annual cyclones contribute to beach erosion. The Forest Department has planted casuarina trees near the shore of many villages, especially those beyond Konapapapeta, to reduce the impact of cyclones. According to the fishers living along the coast north of Kakinada, the beach has been reduced by several hundred meters 58 over the last twenty-five years. It is claimed by some that the Godavari spit, Hope Island, has created currents which have sped up the process, especially at Uppada. In villages like Uppada and Konapapapeta, where the village was originally near the shore, this erosion is most obvious. The beaches there are narrow and the majority of housing has been moved farther inland. In Mulapeta, the village begins beyond a flood plain. From maps of 1903, substantial land has been washed away in Mulapeta during the past 100 years. Furthermore, changing contours of the rivers and sea shore have been observed.

\section{Reviews}

$\left[{ }^{1}\right]$ The Climate system is so complicated to understand since it interacts with each and every object on the earth. This report is about the sea level rise and its impacts due to climate change along the coast of India covering the states of Tamilnadu, Andhra Pradesh, Odhisa, and West Bengal on the East. Agriculture is the major livelihood along the coastal areas of tamilnadu and Andhra Pradesh. The sea level rise impacts can be noticed along the Cauvery delta and Godavari delta, (which are formed by the major rivers of Tamilnadu and Andhra Pradesh) as saltwater intrusion, soil erosion, and reduction in the availability of fishery resources due to increased ocean temperature. Thus the landscape changes due to climate change can be clearly demarcated and also in vice versa, the impacts of Landscape change inducing climate change can be explained as the change in energy flux of incoming solar radiation which is compared with the changes in agricultural areas and shrinking water bodies.

[2] In addition to the mounting empirical data on direct implications of climate change for natural and human systems, evidence is increasing for indirect climate change phenomena such as sea-level rise. Rising sea levels and associated marine intrusion into terrestrial environments are predicted to be among the most serious eventual consequences of climate change. The many complex and interacting factors affecting sea levels create considerable uncertainty in sea-level rise projections: conservative estimates are on the order of $0.5-1.0 \mathrm{~m}$ globally, while other estimates are much higher, approaching $6 \mathrm{~m}$. Marine intrusion associated with 1-6 m sealevel rise will impact species and habitats in coastal ecosystems severely. Examining areas most vulnerable to such impacts may allow design of appropriate adaptation and mitigation strategies. We present an overview of potential effects of $1 \mathrm{~m}$ and $6 \mathrm{~m}$ sea level rise for coastal conservation areas in the Indian Subcontinent. In particular, we examine the projected magnitude of areal losses in relevant biogeographic zones, ecoregions, protected areas (PAs) and important bird areas (IBAs). In addition, we provide a more detailed and quantitative analysis of likely effects of marine intrusion on 22 coastal PAs and IBAs that provide critical habitat for birds in the form of breeding areas, migratory stopover sites and overwintering habitats. Several coastal PAs and IBAs are predicted to experience higher than 50\% areal losses to marine intrusion. We explore consequences of such inundation levels for species and habitats in these areas.

$\left[{ }^{3}\right]$ The coastal zones are highly resourceful and dynamic. The coastal zones are facing many natural hazards such as coastal erosion, Storm surge, Tsunami, coastal flooding and sea level rise. It is obvious that the future sea level rise due to human induced global warming is the main threat to the coastal zone. The global mean sea level is continuing to rise during the 21 st century. In this regards, coastal vulnerability assessment due to sea level rise is needed. Globally, there are many coastal vulnerability assessment tools and techniques such as CM (Common Methodology), SURVAS (Synthesis and Up scaling of Sea Level Rise Vulnerability Assessment Studies), DIVA (Dynamic Interactive Vulnerability Assessment) and CVI (Coastal Vulnerability Index). In the present paper discuss the various aspects of sea level rise and coastal vulnerability index assessment in details.

$\left[{ }^{4}\right]$ Many studies across the globe has predicted the rise in the Sea level as a result of theglobal warming caused by the rising concentration of the atmospheric carbon diooxide,methane, carbon mono oxide and chlorofluorocarbons. The paper aims at analyzing the sea level data from the nine-tide gauge monitoring stations across the country. The most significant and direct impact of the sea level rise may be the shoreline retreat and the loss of the coastal wetland as a result of the inundation of the low land. We attempt to find the time trend of the sea level rise and document the positive, significant and increasing trend for the majority of the monitoring 
stations in India. Total wetland loss along the nine coastal states under different possible scenario and the under projected and estimated trend scenario is evaluated.

$\left[{ }^{5}\right]$ Extreme sea levels generated by strong tangential wind stress and normal atmospheric pressure gradients at the sea surface due to tropical cyclones were studied for the western sector of the Bay of Bengal (the east coast of India). The maritime states along the coast, hit by different intensities of cyclones, are West Bengal, Orissa, Andhra Pradesh, and Tamil Nadu. Based on precise historical data for the period 1891-2007, statistical projections have been made on the probable intensities of tropical cyclones for various return periods. With the help of numerical models developed at Indian Institute of Technology Delhi, maximum probable surges along the coast were simulated. The local tide effect was considered in the computations as rise of sea level would be greater if the cyclone crosses the coast during high tide. The total water elevation is computed by linearly adding the local tide and wave setup to the surge simulated along the coast. In the present study, an assessment of cyclone risk and vulnerability was evolved, which is an important component of the information used to create sustainable local-level development action plans for preparedness and mitigation.

$\left.{ }^{6}\right]$ India has a long coastline of approximately $8,000 \mathrm{~km}$. There are two distinct cyclone seasons: pre-monsoon (May-June) and post-monsoon (October-November). The impact of these cyclones is confined to the coastal districts, the maximum destruction being within $100 \mathrm{~km}$ from the centre of the cyclones and on either side of the storm track. Most casualties are caused due to coastal inundation by tidal waves, storm surges and torrential rains. The occurrence of tropical cyclone is almost a common natural phenomenon. The Indian Ocean is one of the six major cyclones-prone regions of the world. In India, cyclones from Indian ocean usually occur between April and May, and also between October and December. The eastern coastline is more prone to cyclones than the western coast. About 80 percent of total cyclones generated in the region hit the eastern coast. Out of approximately six cyclones formed every year, two to three may be severe.

$\left[{ }^{7}\right]$ Thelivelihood security of the coastal communities and ecological security of the coastal zones of India is already under stress due to high population density, rapid urbanization and industrial development, high rate of coastal environmental degradation and frequent occurrence of natural disasters such as cyclones and storms. This made more than 100 million people, who directly or indirectly depend on coastal natural resources for their livelihood, vulnerable. The problem is going to be further aggravated by increase in sea level rise due to climate change. It has been projected that along the Indian coast sea level would rise by 39 to $57 \mathrm{~cm}$ by 2050 and 78 to $114 \mathrm{~cm}$ by 2100 due to climate change (Unnikrishnan et al, 2006). The coastal zone in India, particularly the east coast is vulnerable to hydrometeorological hazards such as cyclones, floods and geophysical hazards like tsunami. Meteorological data show that more than 1000 cyclonic disturbances occurred in the Bay of Bengal during the last century; out of which over 500 were either depressions and over 400 were either cyclonic storms or severe cyclonic storms. Out of 205 severe cyclones for which records are well documented, 55 affected the coastal zone of Tamil Nadu, 59 crossed the coastal areas of Andhra Pradesh, 58 hit Orissa coast and 33 struck West Bengal. Depending on the location, the risk of hydrometeorological hazards ranges from moderate to high and that of geophysical hazards from low to moderate. A recent simulation study showed an increase in occurrence of cyclones in the Bay of Bengal in the increased Green House Gas scenario, particularly in the postmonsoon period. The same study also indicated that wind speeds associated with cyclones will also reach maximum increased due to climate change (Unnikrishnan et al, 2006)

$\left[{ }^{8}\right]$ India has been traditionally vulnerable to natural disasters on account of its unique geo-climatic conditions. Floods, droughts, cyclones, earthquakes and landslides have been a recurrent phenomena. About $60 \%$ of the landmass is prone to earthquakes of various intensities; over 40 million hectares is prone to floods; about $8 \%$ of the total area is prone to cyclones and $68 \%$ of the area is susceptible to drought. In the decade 1990-2000, an average of about 4344 people lost their lives and about 30 million people were affected by disasters every year. The loss in terms of private, community and public assets has been astronomical.

\section{Erosion control Technics in Area}

The south Indian coast is prone to several water-related natural hazards such as cyclones, storm surges, depressions and flooding. In order to select a feasible coastal protection option, the following studies are required:

1. Seawall (Gentle Slope RMS) Rubble mound made of rocks and Easy to implement and in the Less costly than offshore structures Less capacity to retain the shore line Regular maintenance cost Disruption of access to beach Negative impact on scenery and environment

2. Offshore Breakwater Detached Breakwater parallel to shoreline Reliable trapping of sand Less maintenance cost Most costly Risk of erosion at other beaches Negative impact on scenery Impact on water flows 


\subsection{Coastal management and protection schemes}

Groynes are often not a very satisfactory countermeasure for beach erosion. Their purpose is

to interrupt the littoral drift to try and maintain the beach. However, on their leeside, the supply of sand is interrupted and erosion occurs. In an extreme case, in Kanniyakumari district, groynes were used as a kind of breakwater for fishing by extending the length seaward. The greater length has considerably accelerated the problem of leeside erosion there.

\section{Suggestions}

1. The government built a $3 \mathrm{~km}$ seawall to check the erosion but it offered temporary relief," The government then tried to correct the situation by building a series of groynes, or small breakwaters. This aggravated the problem and erosion spread to neighboring "The structural interventions were done without much thought. It caused saline ingress into groundwater and deprived many of livelihoods in this area.

2. India already has one of the biggest such initiatives, called Integrated Coastal Zone Management Project (ICZMP) financed by the World Bank since 2010. With an estimated cost of US \$286 million, four ICZMP pilot projects have been undertaken in the country - a national coastal management programme and one pilot project each in West Bengal, Odisha and Gujarat. In West Bengal, two areas in the Sundarbans have been identified for ICZMP implementation. Main objectives of the project are conservation of the mangroves, introduction of coastal protection measures, economic development and setting up cyclone shelters. These types of initiative are allocating other coastal sensitive areas in Tamil Nadu and Andhra Pradesh to protect and conservation.

3. In India, coast has been defined in the Coastal Regulation Zone (CRZ) notification of 2011. It says coast is the stretch lying along the seafront up to $500 \mathrm{~m}$ from the high tide line. HTL is the line on the land up to which the highest water line reaches during springtide. Some activists call it a "narrow understanding of coast". But the government perspective differs. Shailesh Nayak, secretary of Ministry of Earth Sciences, says, "Coastal zone is a complex system. It is not an easy task to define it." Development along the coast should happen in a systematic way with minimal impact to the coastal ecosystem, he suggests.

\section{Conclusions}

1. The environments are often subjected to degradation at an alarming rate leaving a very gloomy future. Due to increasing coastal population and growth in mechanized boat operations all along the coastline, the socioeconomic status of the fishermen community is now in a fragile state. It is time that a thorough understanding of the socio-economic status of the coastal population, their limitations to compete with affluent.

2. Fish population is reduced to one fourth due to environmental degradation caused by municipal waste disposal and industrial pollution.

3. The concentration industries and the direct or indirect disposal of industrial disposal of industrial effluents and municipal drains to estuaries, rivers or nearshore waters cause water pollution.

4. In India, a project coming up along the coast needs environmental clearance from the Union Ministry of Environment and Forests (MoEF) if mentioned under the permissible activities in the Coastal Regulation Zone (CRZ) notification of 2011. The project proponent applies to the state coastal zone management authority with an environmental impact assessment (EIA) and a marine impact assessment.

5. Industrial activity is not the only problem ailing the Indian coast. Environmental degradation (urban/industrial waste dumping in sensitive ecosystems, deforestation offshore oil exploration; practices affecting wetlands, mangroves, and marshy lands)

6. Case of cyclones, there is no advance warning systems to warn people of the imminent flooding of their areas, which contribute to further increasing the extent of damages.

7. Uppadas coastal environment is under increasing development pressure, despite the island's exposure to significant shoreline erosion during storm conditions. Buildings need to be designed and constructed to protect human life and assets giving due respect the prevailing forces of nature. With appropriate planning regulations and building practices, Uppadas coastline properties can be protected from damage and a natural or semi-natural appearance preserved. development policies in uppada.

8. Uppada Coast falls under erosion zone, the Consultant should design the Harbour keeping this aspect which is most important for stability of harbour structure duly taking consideration of the previous erosion and siltation history of the said area.

\section{Acknowledgements}

I am very happy to presence first name of the Dr. A.V.V.S.Swamy my Research Guide in Environmental sciences supporting my Research. Special thanks to my own Brother Dr.Ch subhakumar, Dept of 
Economics (A.U) for supervising every steps and editing this paper finally my friend G.Narasimha Rao supporting for financial assistance for publication charges for this paper.

\section{References}

[1]. Praveenkhanna, Udayakumar, Effects of Sea Level Change on Vulnerable East Coast of India, Research Journal of Marine Sciences, 2(1), 2014, 1-5.

[2]. M. Zafar-ul Islam, Shaily Menon, Xingong Li \& A. Townsend Peterson, Forecasting ecological impacts of sea-level rise on coastal conservation areas in India, Journal of Threatened Taxa, 5(9), 2013, 4349-4358.

[3]. Manik Mahapatra, R. Ratheesh and Rajawat, A Sea level rise and coastal vulnerability assessment: a review, International Journal of Geology,Earth \& Environmental Sciences, 3 (3), 2013, 67-80.

[4]. Dwijendra Nath dwivedi, Dr. Vinod Kumar Sharma, Analysis of sea level rise and its impact on coastal wetlands of India, Proceedings of the 14th Biennial Coastal Zone Conference, New Orleans, Louisiana, 2005.

[5]. Indu Jain, A.D. Rao, V. Jitendra, and S.K. Dube, Computation of Expected Total Water Levels along the East Coast of India, Journal of Coastal Research,26 (4), 2010, 681-687.

[6]. Vinod K Sharma, D Kaushik Ashutosh, Natural Disaster Management in India, YOJANA March 2012, 30-36

[7]. V Selvam, Climate change and Disaster Management in Coastal Areas, YOJANA March 2012, 51-55.

[8]. Disaster Management in India - A Status Report , 2004, REPORT Government of India Ministry of Home Affairs National Disaster Management Division.PP2. 